\title{
IMPLEMENTASI LESSON STUDY UNTUK PENINGKATAN KUALITAS PROSES DAN KEMANDIRIAN BELAJAR MAHASISWA
}

\author{
Thathit Manon Andini ${ }^{1)}$, Erly Wahyuni ${ }^{2)}$, Santi Prastiyowati ${ }^{3)}$ \\ FKIP Universitas Muhammadiyah Malang \\ Email'1): bhsing06@yahoo.co.id \\ Email ${ }^{2)}$ :erlywahyuni@ymail.com \\ Email ${ }^{3)}$ :prastiyowati@umm.ac.id
}

\begin{abstract}
ABSTRAK
Program studi pendidikan Bahasa Inggris FKIP UMM adalah LPTK yang bertujuan untuk menghasilkan sarjana pendidikan Bahasa Inggris yang profesional, beriman, dan kompetitif yang mampu berkomunikasi dengan masyarakat pendidikan dan industri. Disamping itu Bahasa Inggris juga bertujuan menyelenggarakan pengembangan penelitian dibidang pendidikan dan sastra Inggris. Dengan harapan Prodi Bahasa Inggris bisa menghasilkan lulusan yang profesional. Guru yang profesional menurut ketentuan PP maupun UUGD adalah guru yang memiliki kompetensi pribadi, kompetensi sosial, kompetensi pedagogi dan kompetensi profesional. Kompetensi pedagogi menghendaki guru memiliki kemampuan merancang, melaksanakan dan mengevaluasi pembelajaran. Sedangkan kompetensi profesional menghendaki Dosen untuk mampu menguasai matapelajaran. Oleh karena itu diperlukan upaya peningkatan kualitas pembelajaran, perlu kiranya diterapkan pembelajaran Introduction to literature dan melalui Lesson Study. Kegiatan Lesson Study ini diterapkan pada mata kuliah Introduction to literature, pada semester Ganjil tahun 2014/2015. Pelaksanaan Lesson Study ini meliputi kegiatan plan, do dan see yang berlangsung dalam 2 (dua) putaran dengan model pembelajaran langsung dengan diskusi kelompok dan presentasi. Indikator peningkatan kemandirian belajar mahasiswa yang teramati meliputi aktivitas memecahkan masalah dengan berdiskusi kelompok dan kemampuan mahasiswa mempresentasikan hasil belajar mahasiswa serta kemampuan kritis dalam tanya jawab. Mata Kuliah Introduction to Literature pada putaran pertama, mempelajari perbedaan karya sastra antara short story, novel, drama dan puisi. Kesiapan dalam mempersiapkan materi perkuliahan secara mandiri 53\%, Keaktifan mengikuti kegiatan perkuliahan 80\%, Keaktifan berdiskusi dengan kelompoknya $71 \%$, tanya jawab dengan dosen $44 \%$. Pada Putaran II, Kesiapan mempersiapkan materi perkuliahan secara mandiri 89\%, Keaktifan mengikuti kegiatan perkuliahan 89\%, Keaktifan berdiskusi dengan kelompoknya $80 \%$, tanya jawab dengan dosen $62,5 \%$.
\end{abstract}

Kata kunci: Lesson Study, proses belajar, kemandirian belajar

\begin{abstract}
English Language Education Department FKIP UMM is an LPTK purposed to produce professional, religious, and competence bachelors which have the ability to communicate with society of education and industry. Beside that, English Department also has the purpose of developing research in the education and English literature. The vision of English Language department is to produce a professional outcome. Professional teachers according to the PP or UUGD should have personal, social, pedagogy, and professional competence. Pedagogy competence is purposed that the teacher has the ability to design, conduct, and evaluate the learning process, while the
\end{abstract}


professional competence is purposed that the lecturer has the mastery of the lesson. Therefore, to improve the quality of the learning, there is a need to implement Introduction to Literature subject and Lesson Study. This Lesson Study is implemented on the Introduction to Literature on the odd semester 2014/2015. The Lesson Study includes the plan, do, and see conducted in two cycles with direct learning model through group discussion and presentation. The indicator of student's independent learning includes the problem solving by doing group discussion and student's ability to present the result of the study, and also the critical ability in question and answer. For the first cycle on Introduction to Literature subject, the study is learning about the difference of literary works such as short story, novel, drama, and poem. The readiness on the preparation of class material of individual is $53 \%$, the activeness on the class is $80 \%$, the activeness on discussion is $71 \%$, question and answer with the lecturer is $44 \%$. On the second cycle, the individual readiness on preparing the material for the class is $89 \%$, the activeness on the class is $89 \%$, the activeness of group discussion is $80 \%$, question and answer with lecturer is $62.6 \%$.

Keywords: Lesson Study, learning process, independent study.

\section{PENDAHULUAN}

Program studi pendidikan Bahasa Inggris FKIP UMM adalah LPTK yang bertujuan untuk menghasilkan sarjana pendidikan Bahasa Inggris yang profesional, beriman, dan kompetitif yang mampu berkomunikasi dengan masyarakat pendidikan dan industri. Disamping itu Bahasa Inggris juga bertujuan menyelenggarakan pengembangan penelitian dibidang pendidikan dan sastra Inggris. Dengan harapan Prodi Bahasa Inggris bisa mengahsilkan lulusan yang profesional. Guru yang profesional menurut ketentuan PP maupun UUGD adalah guru yang memiliki kompetensi pribadi, kompetensi sosial, kompetensi pedagogi dan kompetensi profesional. Kompetensi pedagogi menghendaki guru memiliki kemampuan merancang, melaksanakan dan mengevaluasi pembelajaran. Sedangkan kompetensi profesional menghendaki Dosen untuk mampu menguasai matapelajaran. Oleh karena itu diperlukan upaya peningkatan kualitas pembelajaran, perlu kiranya diterapkan pembelajaran Introduction to literature dan Listening Coprehension melalui Lesson Study.
Kegiatan Lesson Study ini diterapkan pada mata kuliah Introduction to literature dalam semester Ganjil tahun 2014/2015. Pelaksanaan Lesson Study ini meliputi kegiatan plan, do dan see yang berlangsung dalam 4 (empat) siklus. Pada kegiatan Plan, maka rencana pelaksanaan pembelajaran (RPP) masing-masing Dosen akan dibahas secara bersama-sama dengan dosen yang lain dalam forum open plan. Pada kegiatan DO Dosen melaksanakan proses pembelajaran dalam yang diobservasi oleh teman Dosen yang lain, tim observer beberapa orang dosen yang tergabung dalam rumpun matakuliah. Pada kegiatan See, refleksi yang dilakukan untuk menilai proses pembelajaran telah dilaksanakan bersama dengan para observer dan dipimpin oleh moderator. Disamping itu juga dilakukan identifikasi terhadap permasalahan pembelajaran yang muncul dari perencanaan maupun pelaksanaan pembelajaran oleh mahasiswa.

Pada setiap siklus dilakukan identifikasi terhadap pencapaian tujuan matakuliah. Hasil identifikasi merupakan data yang selanjutnya dianalisis secara kualitatif untuk menentukan tingkat pencapaian tujuan matakuliah Introduction to litera- 
ture. Hasil analisis untuk mengetahui peningkatan kemandirian mahasiswa.

\section{METODE}

1. Deskriptif

Penelitian ini merupakan penelitian deskriptif dengan mengimplementasikan Lesson Study. Subyek penelitian ini adalah mahasiswa angkatan 2013 kelas C yang berjumlah 56 mahasiswa dan mahasiswa angkatan 2012 kelas D yang sedang menempuh MK Drama yang berjumlah 50 mahasiswa. Lesson Study dilakukan dalam 3 putaran dengan tahapan (1) Perencanaan (Plan), (2) Pelaksanaan (Do), dan Refleksi (See).

2. Pengamatan

Data-data proses belajar mengajar diperoleh dengan pengamatan peneliti dan teman sejawat yang menjadi pengamat (observer). Pengamatan dilakukan untuk mendapatkan informasi mengenai (1) kesiapan mempersiapkan materi perkuliahan secara mandiri, (2) keaktifan mengikuti kegiatan perkuliahan, dan (3) keaktifan berdiskusi dengan kelompoknya.

\section{HASIL DAN PEMBAHASAN}

\section{Putaran I}

\section{Perencanaan (Plan)}

Plan dilakukan dengan menyususn Rencana Pembelajaran (RPP) dengan model pembelajaran langsung, menyusun lembar Kerja mahasiswa, menyiapkan media pembelajaran, menyiapkan materi pembelajaran, menyiapkan instrumen dan lembar penilaian, serta menyiapkan lembar observasi. Pengelompokan kelompok mahasiswa pada putaran I. Bahan/materi perbedaan short story, novel, drama puisi sudah diinformasikan pada pertemuan sebelumnya. RPP didiskusikan dengan Ibu-ibu observer.

\section{Pelaksanaan ((DO)}

Dosen model sudah datang sudah ada beberapa mahasiswa yang datang lebih dulu dan selanjutnya diikuti oleh teman sejawat sebagai observer. Dosen membagikan lembar observasi kepada Ibu-ibu observer untuk diisi untuk mendapatkan data atau informasi selama kegiatan belajar mengajar berlangsung sebagai bahan refleksi untuk kegiatan pada putaran berikutnya. Langkah-langkah Do pada putaran I adalah: (1) mahasiswa berkelompok sesuai dengan pembagian kelompok sebelumnya, (2) mahasiswa berdiskusi dengan temanteman seklompoknya tentang perbedaan short story, novel, drama dan poetry, (3) mahasiswa menyimpulkan bebagai pendapat dari masing-masing mahasiswa, (4) mahasiswa menuliskan hasil diskusi, (5) perwakilan mahasiswa mempresentasikan hasil diskusinya di depan kelas,(6) presentasi dan tanya jawab, (7) penutup/penguatan materi dosen dan mahasiswa

\section{Implementasi/Observasi}

Dalam Putaran I, kegiatan belajar yang terdokumentasikan adalah sebagai berikut: 
Tabel 1. Kemandirian Belajar Putaran I

\begin{tabular}{|c|l|c|c|}
\hline No & \multicolumn{1}{|c|}{ Indikator Kemandirian Belajar } & $\begin{array}{c}\text { Jumlh siswa } \\
\text { aktif }\end{array}$ & $\%$ \\
\hline 1 & $\begin{array}{l}\text { Kesiapan mempersiapkan materi } \\
\text { perkuliahan secara mandiri }\end{array}$ & 30 & $53 \%$ \\
\hline 2 & $\begin{array}{l}\text { Keaktifan mengikuti kegiatan } \\
\text { perkuliahan }\end{array}$ & 45 & $80 \%$ \\
\hline 3 & $\begin{array}{l}\text { Keaktifan berdiskusi dengan } \\
\text { kelompoknya. }\end{array}$ & 40 & $71 \%$ \\
\hline 4 & Tanya jawab dengan dosen & 25 & $44 \%$ \\
\hline & Total & 56 & \\
\hline
\end{tabular}

\section{Refleksi (SEE)}

Hasil refleksi Putaran I:

1. Mahasiswa / kelompok belum mengenakan pengenal sehingga sulit bagi obserever mengenali masingmasing mahasiswa

2. Situasi kelas kurang semangat jadi kelas terasa vakum karena kehadiran Ibu-ibu observer

3. Masih dijumpai mahasiswa yang belum siap dengan materi yang akan didiskusikan sehingga yang yang siap presentasi hanya 2 kelompok dari 8 kelompok.

4. Masih nampak mahasiswa kurang aktif dalam berdiskusi. Hal ini dikarenakan dalam satu kelompok ada bebrapa mahasiswa yang dominan karena memang termasuk mahasiswa yang lebih pandai daripada yang lainnya

Upaya perbaikan pembelajaran untuk Putaran selanjutnya (II) yaitu sebagai berikut:

1. Mahasiswa mengenakan tanda pengenal berupa nama mahsiswa

2. Dosen model menyarankan mahasiswa rileks, tidak tegang walaupun ada beberapa Ibu sebagai observer

3. Dosen model menjelaskan tentang materi berikutnya dan mengingatkan mahasiswa untuk lebih siap

4. Pembagian kelompok berdasarkan kemampuan dan gender

\section{Putaran II}

Perencanaan (Plan)

Plan dilakukan dengan menyususn Rencana Pembelajaran (RPP) dengan model pembelajaran langsung, menyusun lembar Kerja mahasiswa, menyiapkan media pembelajaran, menyiapkan materi pembelajaran, menyiapkan instrumen dan lembar penilaian, serta menyiapkan lembar observasi. Pengelompokan kelompok mahasiswa pada putaran II berdasarkan pada kemampuan masing mahasiswa dan sebaran laki-perempuan diratakan. Bahan/ materi puisi sudah diinformasikan pada pertemuan sebelumnya.

\section{Pelaksanaan (DO)}

Dosen model sudah datang sudah ada beberapa mahasiswa yang datang lebih dulu dan selanjutnya diikuti oleh teman sejawat sebagai observer. Dosen membagikan lembar observasi kepada Ibu-ibu observer untuk diisi untuk mendapatkan data atau informasi selama 
kegiatan belajar mengajar berlangsung sebagai bahan refleksi untuk kegiatan pada putaran berikutnya. Langkah-langkah Do pada putaran II adalah: (1) mahasiswa berkelompok sesuai dengan pembagian kelompok sebelumnya, (2) mahasiswa berdiskusi dengan teman-teman sekelompoknya untuk memahami element dari Poetry (3) mahasiswa menyimpulkan bebagai pendapat dari masing-masing mahasiswa, (4) mahasiswa menuliskan hasil diskusi dan mereka mengekpresikan dalam bentuk tulis, (5) perwakilan mahasiswa membacakan hasil puisinya di depan kelas,(6) anggota dari kelompok yang lain memeprhatikan pemabcaan puisi darai kelompok lainnya, (7) penutup/ penguatan materi dosen dan mahasiswa.

\section{Implementasi/Observasi}

Dalam Putaran II, kegiatan belajar yang terdokumentasikan adalah sebagai berikut:

Tabel 2. Kemandirian Belajar Putaran II

\begin{tabular}{|c|l|c|c|}
\hline No & \multicolumn{1}{|c|}{ Indikator Kemandirian Belajar } & $\begin{array}{c}\text { Jumlh siswa } \\
\text { aktif }\end{array}$ & $\%$ \\
\hline 1 & $\begin{array}{l}\text { Kesiapan mempersiapkan materi } \\
\text { perkuliahan secara mandiri }\end{array}$ & 50 & $89 \%$ \\
\hline 2 & $\begin{array}{l}\text { Keaktifan mengikuti kegiatan } \\
\text { perkuliahan }\end{array}$ & 50 & $89 \%$ \\
\hline 3 & $\begin{array}{l}\text { Keaktifan berd iskusi dengan } \\
\text { kelompoknya }\end{array}$ & 45 & $80 \%$ \\
\hline 4 & Tanya jawab dengan dosen & 56 & $62,5 \%$ \\
\hline & Total & & \\
\hline
\end{tabular}

\section{Refleksi (SEE)}

Hasil refleksi Putaran II adalah sebagai berikut:

1. Mahasiswa sudah memakai pengenal

2. Situasi kelas sudah lebih kondusif dan mahasiswa sudah rilek

3. Beberapa mahasiswa masih bingung berapa paragraph puisi yang harus ditulis

4. Beberapa mahasiswa masih belum jelas tentang penulisan judul

5. Mahasiswa masih bingung tema apa yang harus ditulis

Upaya perbaikan pembelajaran untuk Putaran selanjutnya (III) yaitu sebagai berikut:
1. Dosen model sebaiknya menjelaskan berapa paragraph yang harus ditulis

2. Mahasiswa dijelaskan bagaimana menemukan judul

3. Mahasiswa perlu dijelaskan tema apa yang harus ditulis

\section{SIMPULAN}

Berdasarkan hasil penelitian tentang kemandirian belajar pada Mata Kuliah Introduction to Literature pada putaran pertama, mempelajari perbedaan karya sastra antara short story, novel, drama dan puisi. Kesiapan dalam mempersiapkan materi perkuliahan secara mandiri 53\%, Keaktifan mengikuti kegiatan perkuliahan $80 \%$, Keaktifan berdiskusi dengan 
kelompoknya $71 \%$, tanya jawab dengan dosen 44\%. Pada Putaran II, Kesiapan mempersiapkan materi perkuliahan secara mandiri 89\%, Keaktifan mengikuti kegiatan perkuliahan 89\%, Keaktifan berdiskusi dengan kelompoknya 80\%, tanya jawab dengan dosen $62,5 \%$.

\section{DAFTAR PUSTAKA}

Arp, Thomas R. and Johnson, Greg. 2006.

Literature: Structure. Sound, and Sense. Australia: Thomson Wadsworth.

Lazar,Gillian.2002.Literature and Language Teaching-A Guide for Teachers and Trainers. United Kingdom: Cambridge University Press 